\title{
Population Divergence of Melipona scutellaris (Hymenoptera: Meliponina) in Two Restricted Areas in Bahia, Brazil
}

by

\author{
Cristovam Alves de Lima Junior ${ }^{1}$, Carlos Alfredo Lopes de Carvalho', \\ Lorena Andrade Nunes ${ }^{2} \&$ Tiago Maurício Francoy ${ }^{3}$
}

\begin{abstract}
Melipona scutellaris Latreille has great economic and ecological importance, especially because it is a pollinator of native plant species. Despite the importance of this species, there is little information about the conservation status of their populations. The objective of this study was to assess the diversity in populations of $M$. scutellaris coming from a Semideciduous Forest Fragment and an Atlantic Forest Fragment in the Northeast Brazil, through geometric morphometric analysis of wings in worker bees. In each area, worker bees were collected from 10 colonies, 10 workers per colony. To assess the diversity on the right wings of worker bees, 15 landmarks were plotted and the measures were used in analysis of variance and multivariate analysis, principal component analysis, discriminant analysis and clustering analysis. There were significant differences in the shape of the wing venation patterns between colonies of two sites (Wilk's $\lambda=0.000006 ; \mathrm{p}<0.000001$ ), which is probably due to the geographical distance between places of origin which impedes the gene flow between them. It indicates that inter and intrapopulation morphometric variability exists $(\mathrm{p}<0.000001)$ in $M$. scutellaris coming from two different biomes, revealing the existence of diversity in these populations, which is necessary for the conservation of this bee species.

KEY WORDS: Geometric morphometrics, diversity, conservation.

\footnotetext{
${ }^{1}$ Insecta Research Group, Centro de Ciências Agrárias, Ambientais e Biológicas, UFRB, C. Postal: 118, 44380-000, Cruz das Almas-BA. Brazil.E-mail: cristovamalves@yahoo.com.br; calfredo@ufrb. edu.br

${ }^{2}$ Escola Superior de Agricultura “Luiz de Queiroz", Universidade de São Paulo, 13418-900, PiracicabaSP. Brazil.E-mail; lorenunes1@yahoo.com.br

${ }^{3}$ Escola de Artes Ciências e Humanidades, Universidade de São Paulo, 03828-000, São Paulo-SP. Brazil.E-mail: tfrancoy@usp.br
} 


\section{INTRODUCTION}

The bees of the genus Melipona Illiger, 1806 occur throughout the Neotropical region, and this genus that has the largest number of species in the subtribe Meliponina (Silveira et al. 2002).

Among the species of Melipona occurring in Bahia State, in Northeast Brazil, M. scutellaris Latreille 1811, M. quadrifasciata Lepeletier 1836 and M. mandacaia Smith 1863, have an emphasis as honey producers (Carvalho et al. 2003).

Despite its economic and ecological importance, there are few studies about the current state of the populations conservation of these species. According to Nunes et al. (2007), this kind of information is important in the preparation of management plans for the preservation of M. scutellaris, since human actions, such as deforestation, use of insecticides and inadequate management of colonies, result in a decrease in populations of stingless bees and the consequential loss of biodiversity.

In this context, the use of morphometric techniques have been used as a tool for morphological, taxonomic, phenotypic and geographic studies among and within bee populations, as in the works carried out by Crewe $e t$ al. (1994), Diniz-Filho \& Malaspina (1996), Araujo et al. (2004), Mendes et al. (2007) and Francoy et al. (2011).

Among the morphometric methods, geometric morphometrics provides powerful tools for the study of morphological variation among populations and therefore offers promising prospects for many problems such as the study of biodiversity patterns (Albert et al. 2001). In this technique, the first step is the definition of a structure and landmarks that are homologous among organisms under study (Monteiro \& Reis 1999).

In bees, wings have been used in morphometric analysis because they are quite flat structures and due to the ease of measuring the size and shape (Diniz-Filho \& Bini 1994, Nunes et al. 2007).

The objective of this work was to study the population divergence through the shape of wing venation of worker bees in M. scutellaris, originating from colonies living in two restricted areas, a semideciduous forest fragment in the Chapada Diamantina and an Atlantic forest fragment area in the coastal zone in the State of Bahia. 


\section{MATERIAL AND METHODS}

Populations of M. scutellaris were sampled between January and February 2009 in two restricted areas, one in an Atlantic forest fragment coastal zone in the city of Vera Cruz, Bahia, Itaparica Island (12 $57^{\prime} 37^{\prime \prime} S$; 38 $36^{\prime} 31^{\prime \prime} \mathrm{W}$; Altitude: $13 \mathrm{~m}$ ) and the other in a semideciduous forest fragment in the Chapada Diamantina region, in the municipality of Novo Mundo, Bahia $\left(12^{\circ} 02^{\prime} 59^{\prime \prime} \mathrm{S}\right.$ and $40^{\circ} 29^{\prime} 43^{\prime \prime} \mathrm{W}$, altitude $\left.604 \mathrm{~m}\right)$. These areas have a distance of $230 \mathrm{~km}$ between them.

Traits of the right forewings of worker bees were used, with 10 workers of each colony and 10 colonies per area, totaling 200 subjects from 20 colonies. The colonies were named according to the place of origin, and to the Semideciduous Forest Fragment - colonies SFF 01 to 10, and the Atlantic Forest Fragment - colonies AFF 01 to 10 . The wings were removed and placed between two plates to capture images with the Motic $2.0 \mathrm{ML}$ program using a digital camera coupled to a stereomicroscope, with 7.5 X magnification. The wings of each subject were identified and stored in Eppendorf tubes of 1.5 $\mathrm{ml}$ and deposited at the Núcleo de Estudos dos Insetos (Experimental Center for the Studies of Insects) (INSECTA), at the Centro de Ciências Agrárias, Ambientaise Biológicas (Center of Agricultural, Environmental and Biological Sciences) of the Federal University of Reconcavo of Bahia.

\section{Geometric Morphometric Analysis}

15 landmarks on the forewing were defined and recorded using the tpsDig program, version 2.12 (Rohlf 2008a) as shown in Fig. 1.

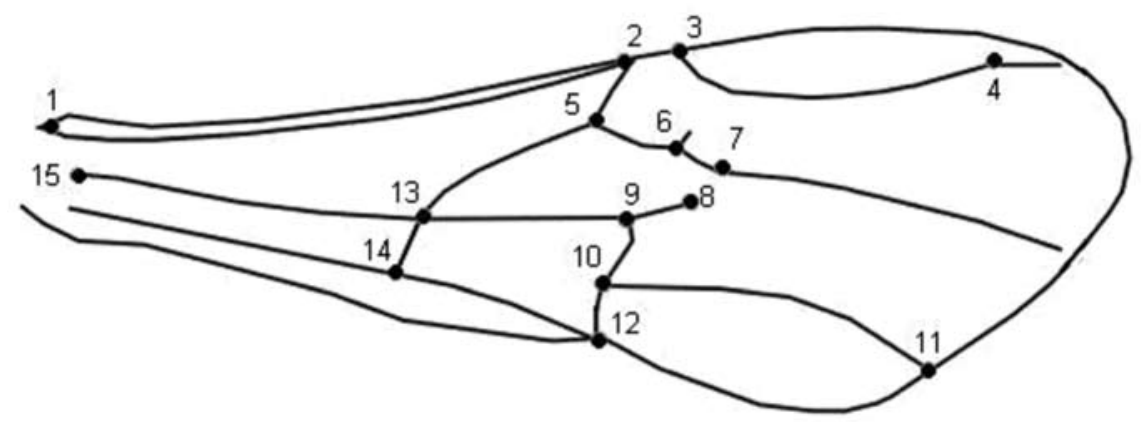

Fig. 1. Landmarks used in morphometric analysis of the forewing of Melipona scutellaris. 
With the tpsRelw program, version 1.46 (Rohlf 2008b), using the archive of recorded images of landmarks, we extracted the $\mathrm{x}$ and y coordinates of each landmark of the aligned wings (alx and aly), the centroid size of the wings and the matrix W which consists of the deformed partial scores plus the estimate of the uniform components (Rohlf 1996). This matrix W can be used as a data matrix in order to perform various multivariate analyzes (Rohlf 2008b).

Centroid size is the square root of the sum of squared distances from each landmark to the centroid (center of mass of the configuration), and this measure is, in the absence of allometry (correlation of size and shape), the only variable size that is not correlated with the variables of form (Rohlf 2008b).

The partial deformation vectors are generated from the projection of the coordinates of each subject in the main deformation, in this way the partial distortions are the characteristics of each subject and are interpreted as the coordinates of each specimen (Ferreira 2009).

The uniform components are calculated from all the landmarks in relation to the average shape and express information on a global scale (uniform) of the shape variation (Monteiro \& Reis 1999).

The visualization of the displacement of landmarks and the deformation grids was performed using the MorphoJ software, version $1.02 \mathrm{~g}$ (Klingenberg 2011).

The programs used for morphometric analysis are available on http://life. bio.sunysb.edu/morph.

\section{Statistical Analysis}

The coordinates of the landmarks of the aligned wings and the centroid size were used in principal component analysis (PCA). The data matrix $\mathrm{W}$ were used in multivariate analysis of variance (MANOVA) and cluster analysis by UPGMA (Unweighted Pair-Group Method using Arithmetic Average) performed with the STATISTICA 9.0 (Stat Soft 2010) program and discriminant analysis performed using the XLSTAT software, Version 2011.1.02. The cophenetic correlation coefficient was calculated by the statistical Genes program (Cruz 2006).

The centroid size was also assessed using an analysis of variance in the statistical STATISTICA 9.0 (Stat Soft 2010) program. 


\section{RESULTS AND DISCUSSION}

\section{Multivariate Statistics}

\section{Principal Component Analysis and Analysis of Multivariate}

\section{Variance}

There were 27 principal components generated using the Cartesian coordinates of landmarks of the aligned wings and the centroid size of the wings. It took the first nine components to explain over $76.0 \%$ of the variation of the data (Table 1).

The separation of the bees by area of origin was plotted graphically in a twodimensional space formed by the scores of the first two principal components that explained $16.95 \%$ and $13.57 \%$ of the variation, respectively (Fig.2).

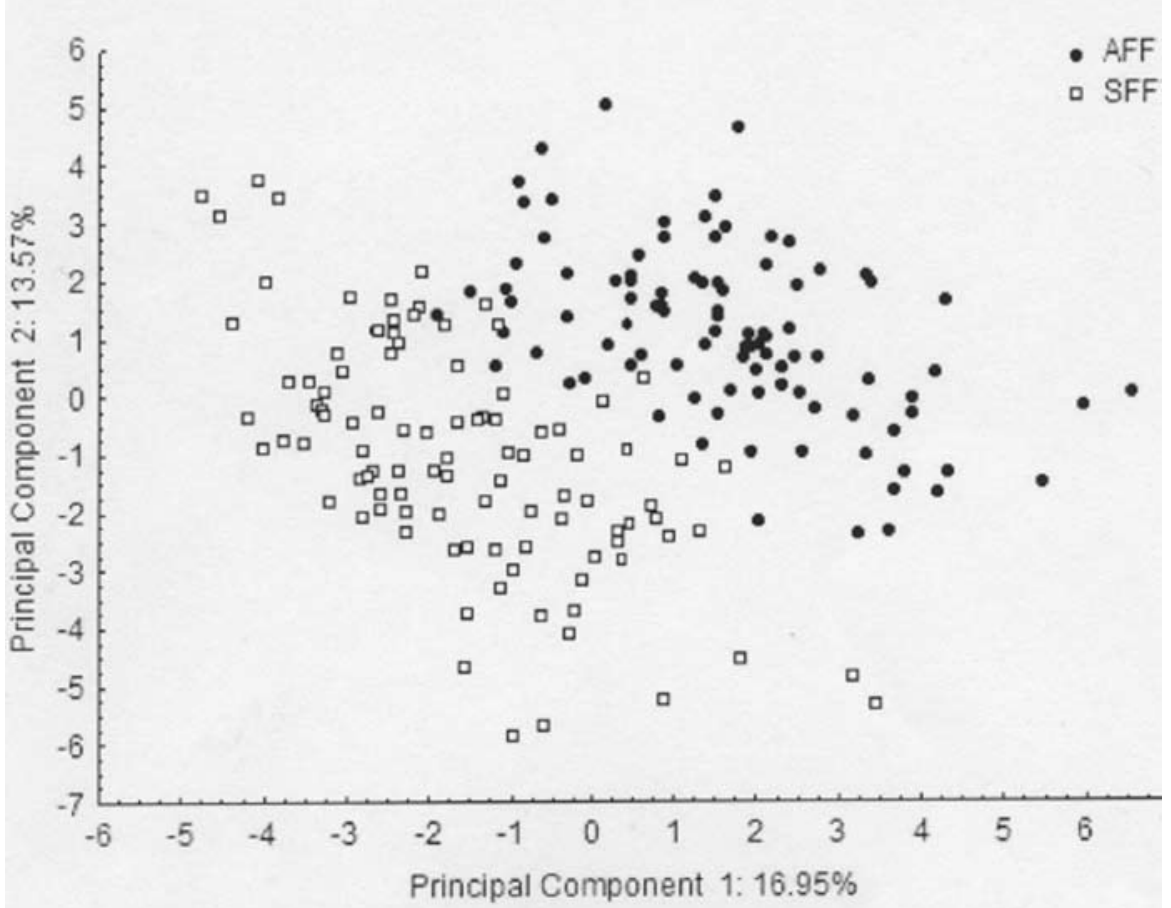

Fig. 2. Dispersal of populations of Melipona scutellaris of two restricted areas in the state of Bahia with the principal component analysis. Points with the same format in the graph represent the worker bees belonging to the respective areas as shown in the legend. SFF = Semideciduous Forest Fragment; $\mathrm{AFF}=$ Atlantic Forest Fragment. 
Table 1. Eigenvalues and total and cumulative variation of the principal components obtained from the Cartesian coordinates of the aligned wing landmarks and the centroid size of the wings of Melipona scutellaris of two restricted areas in the state of Bahia.

\begin{tabular}{|c|c|c|c|c|}
\hline $\begin{array}{l}\text { Principal } \\
\text { Component }\end{array}$ & Eigenvalue & Total Variation (\%) & Cumulative Eigenvalue & Cumulative Variation (\%) \\
\hline 1 & 5.2537 & 16.9475 & 5.2537 & 16.95 \\
\hline 2 & 4.2060 & 13.5677 & 9.4597 & 30.52 \\
\hline 3 & 3.6318 & 11.7155 & 13.0915 & 42.23 \\
\hline 4 & 2.6447 & 8.5313 & 15.7362 & 50.76 \\
\hline 5 & 2.1901 & 7.0647 & 17.9263 & 57.83 \\
\hline 6 & 2.0854 & 6.7270 & 20.0116 & 64.55 \\
\hline 7 & 1.3303 & 4.2914 & 21.3420 & 68.85 \\
\hline 8 & 1.2040 & 3.8840 & 22.5460 & 72.73 \\
\hline 9 & 1.0800 & 3.4839 & 23.6260 & 76.21 \\
\hline 10 & 0.9275 & 2.9920 & 24.5535 & 79.20 \\
\hline 11 & 0.7939 & 2.5610 & 25.3474 & 81.77 \\
\hline 12 & 0.6834 & 2.2044 & 26.0308 & 83.97 \\
\hline 13 & 0.5996 & 1.9340 & 26.6304 & 85.90 \\
\hline 14 & 0.5601 & 1.8069 & 27.1905 & 87.71 \\
\hline 15 & 0.5082 & 1.6395 & 27.6987 & 89.35 \\
\hline 16 & 0.4417 & 1.4249 & 28.1405 & 90.78 \\
\hline 17 & 0.3966 & 1.2795 & 28.5371 & 92.06 \\
\hline 18 & 0.3549 & 1.1448 & 28.8920 & 93.20 \\
\hline 19 & 0.3355 & 1.0824 & 29.2275 & 94.28 \\
\hline 20 & 0.2971 & 0.9584 & 29.5246 & 95.24 \\
\hline 21 & 0.2918 & 0.9411 & 29.8164 & 96.18 \\
\hline 22 & 0.2362 & 0.7620 & 30.0526 & 96.94 \\
\hline 23 & 0.2296 & 0.7405 & 30.2822 & 97.68 \\
\hline 24 & 0.2270 & 0.7322 & 30.5091 & 98.42 \\
\hline 25 & 0.2107 & 0.6797 & 30.7198 & 99.10 \\
\hline 26 & 0.1537 & 0.4959 & 30.8736 & 99.59 \\
\hline 27 & 0.1264 & 0.4079 & 31.0000 & 100.00 \\
\hline
\end{tabular}

Variables aly4, aly9, aly 11 and aly 15 were the ones that contributed most to the first principal component, while for the second principal component, the variables that most influenced it were alx 1 , aly1, and alx2 aly13 (Table 2).

The Multivariate Analysis of Variance (MANOVA) showed the existence of a highly significant difference in the shape of wings between colonies of different areas (Wilk's $\lambda=0.000006 ; \mathrm{p}<0.000001$ ). We also found difference among colonies from the same location (SFF: Wilk's $\lambda=0.000045$; 
$\mathrm{p}<0.000001$ and AFF: Wilk's $\lambda=$ $0.000168 ; \mathrm{p}<0.000001)$, demonstrating the existence of morphometric variability between and within the areas of origin of these colonies. All 26 variables used of the matrix $\mathrm{W}$ used in MANOVA contributed significantly $(\alpha=0.05 \%)$ to the separation of the colony. In a similar context, Francoy et al. (2009) found that the obtained partial deformation of the wings of both males and the worker bees have contributed significantly to the separation of five species of stingless bees. It indicates that the variables obtained in the geometric morphometric analysis can be used to assess the morphometric variability between and within species of bees.

The change of the overall shape shows the greatest variations in the landmarks 04, 11 and 05 (Fig. 3). Sincelandmarks 04 and 11 are located in the extreme points of the wing, it indicates a variation in the total length of this structure among the sampled bees.

The size variation of the wings from the two populations was confirmed whit the significant differences found in the variance analysis of the centroid size $(\mathrm{F}=$ 70.3579; $\mathrm{P}<0.001)$. The bees originating from the semideciduous forest fragment have the centroid size greater than the bees from the Atlantic forest fragment, indicating that the wings of workers of $M$. scutellaris from the Semideciduous Forest
Table 2. Contribution of variables to the principal components obtained from cartesian coordinates of the aligned wing landmarks and the centroid size of Melipona scutellaris. al $\mathrm{x}$ and $\mathrm{al} \mathrm{y}=\mathrm{x}$ and $\mathrm{y}$ coordinates of each landmark of the aligned wings.

\begin{tabular}{lll}
\hline \hline & \multicolumn{2}{c}{ Principal Component } \\
Variable & CP01 & CP02 \\
\hline Centroid Size & -0.550453 & -0.243003 \\
alx1 & -0.042075 & 0.776222 \\
aly1 & -0.306264 & 0.641001 \\
alx2 & -0.188666 & -0.606984 \\
aly2 & 0.202185 & -0.121721 \\
alx3 & -0.177111 & -0.518128 \\
aly3 & -0.250889 & -0.136957 \\
alx4 & 0.656952 & 0.434852 \\
aly4 & -0.787486 & 0.351908 \\
alx5 & -0.630051 & -0.532158 \\
aly5 & -0.199672 & -0.377015 \\
alx6 & 0.343194 & -0.241252 \\
aly6 & 0.165304 & 0.175745 \\
alx7 & 0.236879 & 0.066574 \\
aly7 & 0.276928 & -0.080970 \\
alx8 & 0.207306 & -0.229745 \\
aly8 & 0.524310 & -0.306929 \\
alx9 & 0.194469 & -0.113525 \\
aly9 & 0.754889 & -0.058321 \\
alx10 & 0.148413 & -0.162990 \\
aly10 & 0.533427 & -0.180559 \\
alx11 & -0.687989 & 0.309534 \\
aly11 & 0.542941 & 0.173048 \\
alx12 & 0.381650 & 0.135767 \\
aly12 & 0.202381 & -0.396282 \\
alx13 & -0.425072 & -0.473367 \\
aly13 & -0.273201 & -0.676573 \\
alx14 & 0.002385 & -0.037379 \\
aly14 & -0.014791 & -0.282355 \\
alx15 & -0.073616 & 0.384956 \\
aly15 & -0.685634 & 0.435803 \\
\hline \hline & &
\end{tabular}




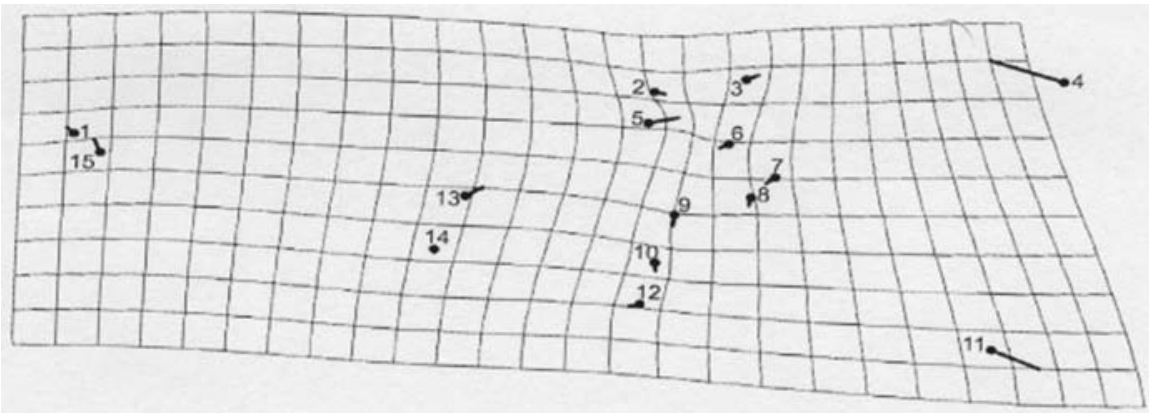

Fig. 3. Deformation grid showing the change in the overall shape of the wings of Melipona scutellaris of two restricted areas in the State of Bahia.

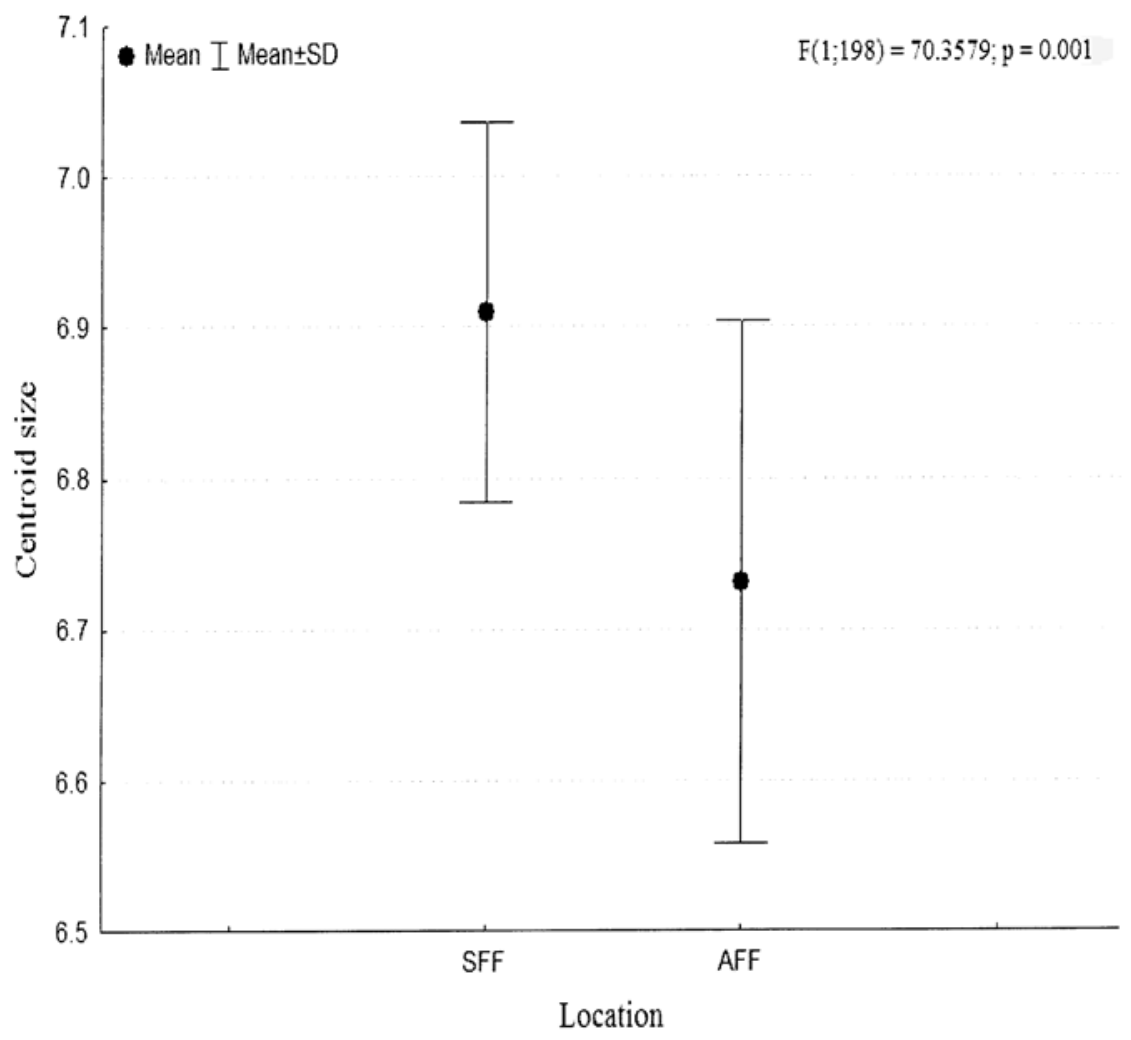

Fig. 4. Wing centroid size of Melipona scutellaris of two restricted areas in the State of Bahia. SFF = Semideciduous Forest Fragment; AFF = Atlantic Forest Fragment. 
Fragment are larger (Fig. 4). Araújo et al. (2004) in studies with six species of stingless bees, among which there were three species of Melipona, revealed that the generalized wing size is strongly correlated to the flight distance, which suggests that the stingless bees occupy a maximum effective space proportional to body size, especially with wing dimensions, which might constitute strong constraints on local populations restricted to forest fragments.

\section{Discriminant Analysis}

In the discriminant analysis performed using the matrix $\mathrm{W}$, it can be seen that $91.0 \%$ of the bees were correctly classified within their respective colonies (Table 3). The Semideciduous Forest Fragment colonies stood out with five colonies that had correct classification rates of $100.0 \%$ (colonies SFF 03, 04, 06, 07 and 10). As for the Atlantic Forest Fragment area, there were four colonies with $100.0 \%$ of correct classification (colonies AFF 01, 03, 04 and 07). The colonies that had the lowest rates of correct classification $(70.0 \%)$ were the colonies SFF 01 and AFF 10. Mendes et al. (2007), noted that in stingless bees, geometric morphometrics can be used as a technique for the discriminant analysis even in small populations.

By cross-validation (Table 3), the average of correct identification of individuals to its correct colony of origin was $72.0 \%$, with the colonies of the AFF 01 and 03 and SFF 06 standing out, which had 100.0\% of subjects correctly identified.

The discriminant analysis performed for the classification of subjects between areas revealed that in the Atlantic Forest Fragment a correct classification rate of $100.0 \%$ was obtained, while the Semideciduous Forest Fragment rate was $99.0 \%$, and the overall average was $99.5 \%$. In cross-validation tests the overall average was $97.5 \%$, and for the Semideciduous Forest Fragment the correct identification of its subjects was $98.0 \%$, while for the Atlantic Forest Fragment the rate was $97.0 \%$.

Despite the absence of a record of discriminant analysis in populations of M. scutellaris, rates of correct classification and identification obtained in this study are considered high when compared to the works of Tofilski (2008) and Francoy et al. (2008), which had rates of 84.9 and $97.8 \%$ of correct identification by cross-validation for discrimination of subspecies of Apis mellifera with geometric morphometric variables, but also with those of Mendes et al. 
Table 3. Classification and correct identification of subjects within their respective colonies and areas of origin by discriminant analysis and cross validation, respectively. $\mathrm{SFF}=$ Semideciduous Forest Fragment $;$ AFF $=$ Atlantic Forest Fragment.

\begin{tabular}{lll}
\hline \hline Colony & Correct Classification (\%) & Correct Identification (\%) \\
\hline SFF 01 & 70.00 & 60.00 \\
SFF 02 & 90.00 & 70.00 \\
SFF 03 & 100.00 & 80.00 \\
SFF 04 & 100.00 & 40.00 \\
SFF 05 & 90.00 & 80.00 \\
SFF 06 & 100.00 & 100.00 \\
SFF 07 & 100.00 & 80.00 \\
SFF 08 & 80.00 & 50.00 \\
SFF 09 & 90.00 & 90.00 \\
SFF 10 & 100.00 & 80.00 \\
AFF 01 & 100.00 & 100.00 \\
AFF 02 & 90.00 & 70.00 \\
AFF 03 & 100.00 & 100.00 \\
AFF 04 & 100.00 & 90.00 \\
AFF 05 & 90.00 & 80.00 \\
AFF 06 & 80.00 & 70.00 \\
AFF 07 & 80.00 & 40.00 \\
AFF 08 & 100.00 & 80.00 \\
AFF 09 & 90.00 & 40.00 \\
AFF 10 & 70.00 & 40.00 \\
Average & 91.00 & 72.00 \\
Area & Correct Classification (\%) & Correct Identification (\%) \\
Semideciduous & 99.00 & 98.00 \\
Forest Fragment & & 97.00 \\
Atlantic Forest & 100.00 & \\
Fragment & 99.50 & \\
Average & & \\
\hline \hline & & \\
\hline
\end{tabular}

(2007) and Francoy et al. (2009) in studies of species of stingless bees that reached from 77.6 to $100.0 \%$ of ratings and from 69.79 to $100.0 \%$ of correct identifications of subjects in respective groups.

Comparing the rates of correct classification and identification considering the areas and also the colonies as a separate group, the highest correct rates found in the discrimination per area can be verified, since these higher rates of classifications and identifications are due to the greater variability in shape that are occurring between the areas of origins of the colonies than among the colonies themselves. 


\section{Cluster Analysis}

The Mahalanobis $\mathrm{D}^{2}$ distances between colonies were calculated for the cluster analysis (Table 4). All distances were statistically significant $(\alpha=0.05)$ indicating the existence of significant differences among the colonies.

Based on the Mahalanobis distance the clustering of the colonies was performed by the method of UPGMA. In the dendrogram obtained (Fig. $5)$ it can be observed the formation of nine groups consisting of: I - colonies SFF 01 and 02; II - colonies SFF 04, 08 and 09; III - colonies SFF 10; IV colonies SFF 03 and 05; V - colonies SFF 06 and 07; VI - Colony AFF 01; VII - colony AFF 02; VIII - Colony AFF 03, and IX - colonies AFF 04, 05 , 06, 07, 08, 09 and 10 .

The cophenetic correlation coefficient (CCC) for the dendrogram was 0.80 ( $\mathrm{p}<0.01)$. The CCC shows a good fit between the graphical representation of the original distances and its original matrix according to Bussab

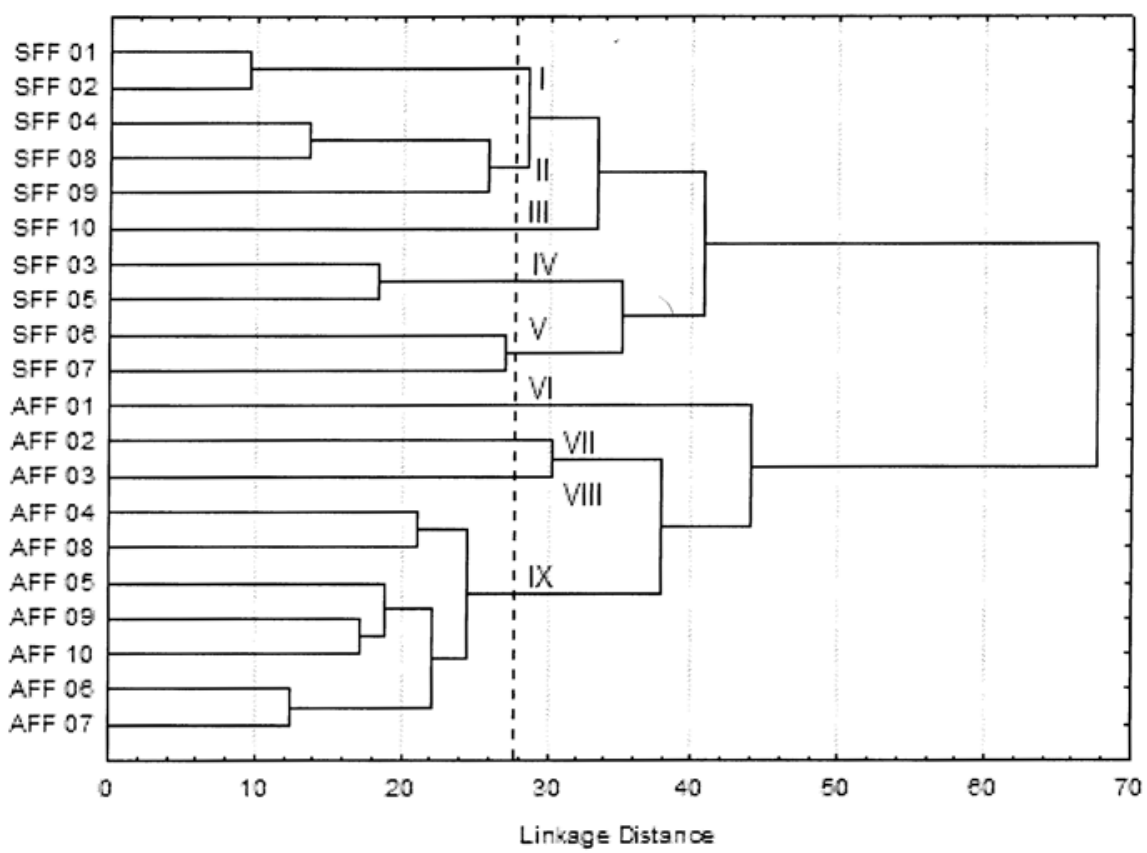

Fig. 5. Dendrogram generated by UPGMA through the Mahalanobis distances between colonies of the Semideciduous Forest Fragment (SFF) and the Atlantic Forest Fragment (AFF). Roman numbers represent the groups formed. 


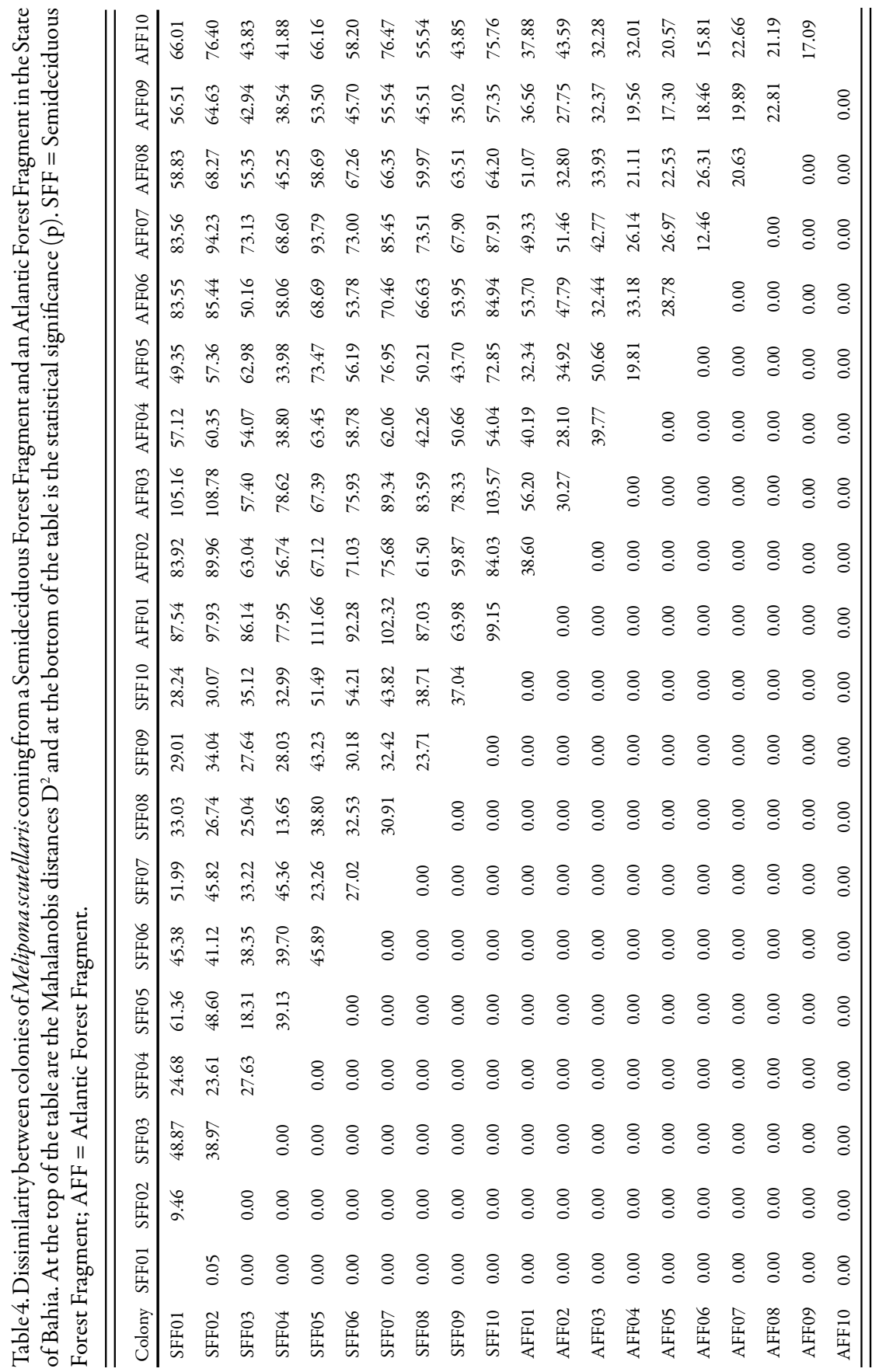


et al. 1990, thus enabling the realization of inferences by means of visual assessment of the figure.

In this dendrogram the formation of groups composed of a variable number of colonies stands out, with the existence of clusters with up to seven colonies (Group IX) and also colonies that are in isolation (Groups III and VI). This group formation reveals the similarity of the shape of wings among the colonies, and colonies grouped into a single set of wings are more similar to each other, while colonies that were isolated have wings more divergent in the populations studied. It was also noted that there is not any clustering of colonies from different origins at any time, which also shows the divergence between these colonies with respect to the location from which they were collected.

According to Francoy \& Imperatriz-Fonseca (2010), the variables generated in geometric morphometrics are independent of the size of structures, which eliminate part of the environmental influence that affects the development of organisms, especially insects. Thus, the shape variation found among the colonies, mainly coming from different areas may be due to genetic differences between these colonies. The subject's phenotype (e.g. morphology, in this case the shape of the wing) is the result of their interaction with genetic and environmental factors and when the effect of these environmental factors is eliminated there is a greater effect of genetics on the phenotype of the subject. As the distance of the stingless bee swarming is short (Kerr et al. 1996), the geographical distance between these environments can be considered as a factor that prevents the exchange of genetic material between the colonies, as there is no reference that there has been any handling or transport of the colonies from one area to another.

Gonçalves (2010), when studying variability in Frieseomelitta varies by geometric morphometrics and molecular analysis of wings, suggested that the genetic diversity found in the small population under study is the result of gene flow via males, which have greater ability to fly and thus may originate from further distant regions and may have fertilized queens of the isolated population, thus introducing new alleles in that population. This hypothesis can also be adopted as the source of the diversity found among colonies of the same geographical origin, because near the locations where the bees were collected from there is a forest area with colonies in their natural state. 
The wing shape variations found in this work show that the use of geometric morphometrics of wings is a simple, practical, inexpensive and important tool in assessing diversity within populations of bees.

\section{CONCLUSION}

The geometric morphometric analysis of wings indicates that inter and intrapopulation morphometric variability exists in Melipona scutellaris coming from a semideciduous forest fragment and an Atlantic forest fragment in the State of Bahia, revealing the existence of diversity in these populations, which is necessary for the conservation of this bee species.

\section{ACKNOWLEDGMENTS}

The authors thank Conselho Nacional de Desenvolvimento Cientifico e Tecnológico (CNPq) (Proc. 303237/2010-4), Coordenação de Aperfeiçoamento de Pessoal de Nivel Superior (CAPES) (AUX-PE-PNPD-1598/2008) for the scholarships and financial support and Dr. Wyratan da Silva Santos for his critiques and suggestions.

\section{REFERENCES}

Addinsoft Sarl 2011. XLSTAT versão 2011.1.02. para Windows.

Alibert P., B. Moureau, J.L. Dommergues \& B. David 2001. Differentiation at a microgeographical scale within two species of ground beetle, Carabus auronitens and $C$. nemoralis (Coleoptera: Carabidae): a geometrical morphometric approach. Zoologica Scripta 30: 299-311.

Araújo, E.D., M. Costa, J. Chaud-Netto \& H.G. Fowler 2004. Body size and flight distance in stingless bees (Hymenoptera: Meliponini): Interference of flight range and possible ecological implications. Brazilian Journal of Biology 64: 563-368.

Bussab, W.O., E.S. Miazaki \& D.F. Andrade 1990. Introdução à análise de agrupamentos. São Paulo: IME/USP. 105 p.

Carvalho, C.A.L., R.M.O. Alves \& B.A. Souza 2003. Criação de abelhas sem ferrão: aspectos práticos. Cruz das Almas: Universidade Federal da Bahia/SEAGRI. 42 p. (Série Meliponicultura - 01).

Crewe, R.M., H.R. Hepburn \& R.F.A. Moritz 1994. Morphometric analysis of 2 southern African races of honey bee. Apidologie 25: 61-70.

Cruz, C.D. 2006. Programa Genes - Biometria. 1. ed. Viçosa, MG: Editora UFV. 382 p.

Diniz-Filho, J.A.F. \& L.M. Bini 1994. Space-free correlation between morphometric and climatic data: a multivariate analysis of Africanized honey bees (Apis mellifera L.) in Brazil. Global Ecology and Biogeography. Letters 4: 195-202. 
Diniz-Filho, J.A.F. \& O. Malaspina 1996. Geographic variation of Africanized honey bees (Apis mellifera) in Brazil - multivariate morphometrics and racial admixture. Brazilian Journal of Genetics 19: 217-224.

Ferreira, V.S. 2009. Análise morfométrica e genética da variabilidade em populações de Centris (Centris) aenea Lepeletier, 1841 (Hymenoptera, Apidae, Centridini), uma abelha polinizadora de fruteiras. Dissertação de Mestrado, Universidade Estadual de Santa Cruz, Ilhéus-BA. 78 p.

Francoy, T.M., D. Wittmann, M. Drauschke, S. Müller, V. Steinhage, M.A.F. Bezerra-Laure, D. De Jong \& L.S. Gonçalves 2008. Identification of Africanized honey bees through wing morphometrics: two fast and efficient procedures. Apidologie, 39: 488- 494.

Francoy, T.M., R.A.O. Silva, P. Nunes-Silva, C. Menezes \& V.L. Imperatriz-Fonseca 2009. Gender Identification of five genera of stingless bees (Apidae, Meliponini) based on wing morphology. Genetics and Molecular Research 8: 207-214.

Francoy ,T.M. \& V.L. Imperatriz-Fonseca 2010. A morfometria geométrica de asas e a identificação automática de espécies de abelhas. Oecologia Australis 14: 317-321.

Francoy, T.M., M.L. Grassi, V.L. Imperatriz-Fonseca, W.J. May-Itzá \& J.J.G. Quezada-Euán 2011. Geometric morphometrics of the wing as a tool for assigning genetic lineages and geographic origin to Melipona beecheii (Hymenoptera: Meliponini). Apidologie, 42: 499- 507.

Gonçalves, P.H.P.2010. Análise da variabilidade de uma pequena população de Frieseomelitta varia (Hymenoptera, Apidae, Meliponini), por meio de análise do DNA mitocondrial, microddatélites e morfometria geométrica das asas. Dissertação de Mestrado, Universidade de São Paulo, São Paulo-SP. 140 p.

Kerr, W.E., G.A. Carvalho \& V.A. Nascimento. 1996. Abelha Uruçu: Biologia, Manejo e Conservação. Belo Horizonte- MG, Ancagaú. 143p.

Klingenberg, C. P. 2011. MorphoJ: an integrated software package for geometric morphometrics. Molecular Ecology Resources 11: 353-357.

Mendes, M.F.M., T.M. Francoy, P. Nunes-Silva, C. Menezes \& V.L. Imperatriz-Fonseca 2007. Intra-populational variability of Nannotrigona testaceicornis Lepeletier 1836 (Hymenoptera, Meliponini) using relative warp analysis. Bioscience Journal 23: 147 152.

Monteiro, L.R. \& S.F. Reis 1999. Princípios de morfometria geométrica. Ribeirão Preto: Holos. 188p.

Nunes, L.A., M.F.F.C. Pinto, P. Carneiro, D.G. Pereira \& A.M. Waldschmidt 2007. Divergência Genética em Melipona scutellaris Latreille (Hymenoptera: Apidae) com base em Caracteres Morfológicos. Bioscience Journal 23: 1-9.

Rohlf, F.J. 1996. Morphometric spaces, shape components and the effect of linera transformations, p. 117-130. In Marcus LF, Corti M, Loy A, Naylor G, Slice D (Ed.) Advances in Morphometrics. New York: Plenum Publishind Corp. 587p.

Rohlf, F.J. 2008a. Program tpsDIG2 for Windows version 2.12. Departament of Ecology and Evolution, State University of New York, Stony Book.

(http://life.bio.sunysb.edu/morph/index.html, acessado em 21/outubro/2008). 
Rohlf, F.J. 2008b. Program tpsRelw version 1.46. Department of Ecology and Evolution, State University of New York, Stony Book. (http://life.bio.sunysb.edu/morph/index. html, acessado em 21/outubro/2008).

Stat Soft 2010. Statistica for windows: versão 9.0. Tulsa.

Tofilski, A.2008. Usinggeometric morphometrics and standard morphometry to discriminate three honeybee subspecies. Apidologie 39:558-563.

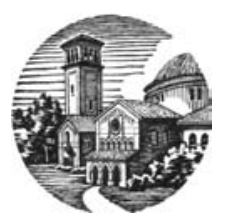

